\title{
Correction to: Fluorescence Study of Sinapic Acid Interaction with Bovine Serum Albumin and Egg Albumin
}

\section{Bogdan Smyk ${ }^{1}$}

Published online: 11 September 2020

(C) Springer Science+Business Media, LLC, part of Springer Nature 2020

Correction to: Journal of Fluorescence (2003) 13:349-356 https://doi.org/10.1023/A:1025334029406

The original version of this article unfortunately contained a mistake. The captured city in the affiliation was misspelled. The corrected affiliation is given below.

Publisher's Note Springer Nature remains neutral with regard to jurisdictional claims in published maps and institutional affiliations.

The online version of the original article can be found at https://oi.org/ 10.1023/A:1025334029406

Bogdan Smyk

bsmyk@uwm.edu.pl

1 Department of Physics and Biophysics, University of Warmia and Mazury in Olsztyn, 10-719 Olsztyn, Poland 